\title{
The Effect of Turkish Folk Tales on Students' Attitudes towards Human Values
}

\author{
Mustafa TAHİROĞLU* \\ Onur Alp KAYABAŞI ${ }^{* *}$ \\ R. Gökcen KAYABAŞI ${ }^{* * *}$
}

Received: 29 March 2013

Accepted: 28 May 2013

\begin{abstract}
In this study, it is aimed to investigate the effect of values education-related activities through Turkish folk tales on 8th graders' attitudes towards human values. For this purpose, some Turkish folk tales which concentrate on responsibility, friendship/companionship, peace, respect, tolerance and honesty were selected and taught in accordance with the methods of values education. An experimental pre-test - post-test control group design was used in the study. There were 22 students in the experimental group and 20 students in the control group. To collect the data, the "Human Values Scale" was administered. Independent-samples $t$ tests were used to analyze the data. As a result, significant differences were found in favor of the experimental group [ $t(40)=8.899, p<0.05]$. According to this, values education-related activities through Turkish Folk tales had positive impact on 8th graders' attitudes towards human values such as responsibility, friendship / companionship, peace, respect, tolerance and honesty.
\end{abstract}

Keywords: values, Turkish folk tales, attitude, value education

\section{Extended Abstract}

Purpose and Significance: It is a reality acknowledged by all people that today's society is confronted with many serious issues such as socio-economical instability, wars, increase in violence, intolerance, deformation of the ecological balance, etc. In order to cope with these issues, human, ethical and spiritual values should be gained by young people in a society to establish love, friendship, happiness, freedom and peace. What is considered as the most appropriate way of effectively gaining of those values by next generations is to benefit from the cultural elements of a society one of which is tales. Having analyzed some of the relevant studies, it has been concluded that education offered in correspondence with the methods of values education has a positive effect on students' attitudes towards relevant values. Consequently, the purpose of the study is to find out the effect of values education-related activities through Turkish folk tales which significatly form cultural identity of the Turkish society on 8th graders' attitudes towards human values such as "responsibility”, “friendship”, "peace”, "respect”, “tolerance” and "honesty”.

Methodology: In line with the purpose stated above, values education-related activities through Turkish folk tales were developed by the researchers. In the study, An experimental pre-test - post-test control group design was used in the study to find out whether students who have attended those activities differ from those who have not

\footnotetext{
*Ph.D, Nevşehir University, tahiroglu80@hotmail.com

** Corresponding Author:Ph.D, Aksaray University, onuralpkayabasi@hotmail.com

**** Specialist, Aksaray University, rabiagokcen@hotmail.com
} 
attended. The experimental group consisted of 22 students and the control group consisted of 20 students. The "Human Values Scale" (HVS) which was developed by Dilmaç (2007) was used in order to collect data. The scale was composed of 42 items including certain statements regarding values such as "responsibility", "friendship", "peace", "respect", "tolerance" and "honesty". As a result of the analysis, it was determined that the HVS has sufficient levels of validity and reliability required for the study. This scale was administered to both groups simultaneously at the beginning and the end of the intervention. After the pre-test and post-test scores of the experimental and control groups had been obtained, independent-samples $t$ tests were done to compare groups. The reliability level of .05 was considered as the significance level.

Findings: After the data had been analyzed, a difference of 0.71 in favor of the experimental group was found out regarding the post-test administration of the Human Values Scale. When this difference was analyzed through $t$ test with .05 as the level of significance, the $t$ value was found as 8.899 [ $t(40)=8.899, p<0.05]$. This result showed that values education-related activities through Turkish folk tales have positive effect on their attitudes towards human values. Besides, within group-comparisons indicated that not only the current Turkish language curriculum [t(38)=3.835, $p<.05]$, but also values education-related activities through Turkish folk tales [t(42)=8.902, $p<.05$ ] have positive effect on students' attitudes towards human values.

Discussion and Conclusion: As a result of within groups-comparisons, both values education-related activities through Turkish folk tales and the current Turkish language curriculum had significant positive impact on $8^{\text {th }}$ graders' attitudes towards human values, but between groups-comparisons showed that there is a significant difference in favor of the experimental group. In other words, 8th graders imposed to values education-related activities through Turkish folk tales developed more positive attitudes towards human values than those imposed to the current Turkish language curriculum. Also, some of the previous studies (Aktepe, 2010; Aladağ, 2009; Balc1, 2008; Demirtaş, 2009; Dilmaç, 2007; Keskinoğlu, 2008; Koç, 2007; Meaney, 1979) revealed that values education has a positive effect on students' attitudes towards the relevant values. Nevertheless, it would not be correct to say that students have gained these values just because they have developed positive attitudes towards the values. The reason for this is that people own, other than attitudes, certain characteristics such as "aims and goals, wishes, emotions, interests, beliefs and ideas, behaviors, activities and concerns" that demonstrate their values. If researchers want to find out whether a value has been gained to a certain group of students or not, it would be a more appropriate and reliable way to develop measurement tools that will reveal these value indicators and test the effectiveness of the activities in gaining the relevant values. Besides, some of these value indicators are not revealed in the classroom. Therefore, it seems quite difficult to measure exactly the effectiveness of the activities developed in order to gain values. According to the findings of the study, the values education-related activities 
through Turkish folk tales had a positive effect on $8^{\text {th }}$ grader's attitudes towards human values. In this context, Turkish folk tales can be used in values education in a similar way as done in this study or in different ways. However, in this study, the effect of the values education-related activities through Turkish folk tales only on students' attitudes towards human values was investigated. As mentioned above, based upon attitudes toward certain values, it can not be sufficient to find out whether values are gained or not. So, in future studies regarding values education through Turkish folk tales, measurement tools might be developed and used so that other value indicators will be revealed both separately and together. Hence, the effect of folk tales, the significant part of Turkish culture, on children's gaining values will be explicited clearer. 


\title{
Türk Halk Masallarının Öğrencilerin İnsani Değerlere Yönelik Tutumlarına Etkisi
}

\author{
Mustafa TAHİROĞLU* ${ }^{*}$ Onur Alp KAYABAŞI ${ }^{* *} \quad$ R. Gökcen KAYABAŞI ${ }^{* * *}$
}

Makale Gönderme Tarihi: 29 Mart 2013

Makale Kabul Tarihi: 28 May1s 2013

\begin{abstract}
ÖZET: $\mathrm{Bu}$ araştırmada Türk halk masallarından faydalanılarak değerler eğitimi yöntemlerine uygun geliştirilen etkinliklerin, ilköğretim 8. sınıf öğrencilerinin insani değerlere yönelik tutumlarına etkisinin belirlenmesi amaçlanmıştır. Bu amaçla, sorumluluk, dostluk/arkadaşlık, barışçı olma, saygı, hoşgörü ve dürüstlük gibi insani değerler üzerinde yoğunlaştığı düşünülen bazı Türk halk masalları seçilerek değerler eğitimi yöntemlerine uygun bir şekilde işlenmeye çalışılmıştır. Çalışmada ön-test - son-test kontrol gruplu deneme modeli kullanılmıştır. Deney grubu 22, kontrol grubu ise 20 öğrenciden oluşmuştur. Araştırma verilerinin toplanması için her iki gruba deneysel çalışma sürecinin başında ve sonunda "İnsani Değerler Ölçeğì" uygulanmıştır. Verilerin analizinde ilişkisiz örneklemler $t$ testinden yararlanılmıştır. Analiz sonucunda deney ve kontrol grubunun son test ölçüm sonuçları incelendiğinde deney grubu öğrencileri lehine anlamlı bir farklılık olduğu görülmüştür [t(40)=8.899, $p<0.05]$. Bu sonuca göre, Türk halk masallarından faydalanılarak değerler eğitimi yöntemlerine uygun geliştirilen etkinlikler, öğrencilerin sorumluluk, dostluk/arkadaşlık, barışçı olma, saygı, hoşgörü ve dürüstlük gibi insani değerlere ilişkin tutumları ve davranışlarına olumlu bir etki göstermiştir.
\end{abstract}

Anahtar sözcükler: değerler, Türk halk masalları, tutum, değer eğitimi.

\section{Giriş}

Modern toplumun ahlâki değerler açısından ciddi bir problemle karşı karşıya olduğu her kesimden insan tarafından tespit edilen bir vakıa olarak önümüzde durmaktadır. Geçmişte değerler eğitimine çok fazla ihtiyaç duyulmamışken günümüzde evrenselleşme eğilimi birçok insanın kültürel yelpazesini genişletmiştir. Hareketlilikteki bu artış, insanlara hem yurt içinde hem de yurt dışında gerçek ve sanal biçimlerde başka kültürlerin deneyimini kazanmalarına izin vermiştir. Bu durum, insanların yaşamlarında çok fazla değişikliğe ve tutarsızlığa yol açmıştır. İnsanlar yaşamları için bir anlam ve merkez bulmakta zorlanmışlardır. Yeni neslin beslenme, eğitim ve sağlık hizmeti açısından geçmişe kıyasla daha iyi durumda olduğu, ancak pek çok ahlâki sorunla karşı karşıya kaldığı da bir gerçektir. Bu ahlâki sorunları ve sonuçlarını hem birey hem de toplum bazında görmek mümkündür. Ancak insanlığı esas tehdit eden sorunlar küresel bağlamdaki sorunlardır. Bunların başında da dünya çapında sosyo-ekonomik dengesizlikler, savaşlar, çatışma ve şiddet olaylarındaki artışla ekolojik dengenin bozulması gelmektedir. Giderek artan şiddetten, hoşgörüsüzlükten ve diğer problemlerden özellikle çocuklar olumsuz bir şekilde etkilenmektedirler (Arslan \& Yaşar, 2007; Köylü, 2007; Raths, Harmin, \& Simon, 1978; Tillman, 2001; Veugelers \& Kat, 1999).

$\mathrm{Bu}$ problemlerle başa çıkabilinmesi için insanî, etik ve manevi değerlerin kaybını önlemeye; düşünme, hissetme ve hareket etme biçiminde bir geri dönüşe, eğitimsel ve kişisel düşüncede önemli bir değişime ihtiyaç duyulmaktadır. Bu doğrultuda pek çok insan, ihtiyaç duyulan değişimin sağlanması için toplumda sevginin,

\footnotetext{
*Dr, Nevşehir Üniversitesi, tahiroglu80@hotmail.com

** Sorumlu Yazar: Dr., Aksaray Üniversitesi, onuralpkayabasi@hotmail.com

${ }^{* * *}$ Uzman, Aksaray Üniversitesi, rabiagokcen@hotmail.com
} 
dostluğun, mutluluğun, özgürlüğün, barışın yaşanması ve oluşturulması gerektiğini, yaratıcılığın ve tutarlılığın en üst düzeyde geliştirilmesi için de etik değerlere uyulması gerektiğini düşünmektedir çünkü insan; düşünen, duyguları olan, bu duyguların farkında olan, bunları paylaşan, yaratan, yarattığını paylaşan ve aktaran, birlikte yaşadığı toplulukla ortak değerleri olan bir varlıktır. Bu sebeple ortak yaşamın temelini oluşturan ve genel kabul gören değerlere sahip olunmalıdır (Sar1, 2005; Thiroux, 1980, aktaran Akbaba-Altun, 2003; Tillman, 2001; United Nations Educational, Scientific and Cultural Organization, 2005).

Değerler son birkaç yılda en gözde kavramlardan biri olarak karşımıza çıkmaktadır. Çağımızda değerlerin bu kadar vurgulanıyor olması, bunların ne kadar önemsendiğini, bu konuda ne kadar ileri bir noktada olduğumuzu göstermez. Günümüzde değerlerin bu denli vurgulanması, değerlere verilen değerin artması değil, değerlere duyulan ihtiyacın artması şeklinde yorumlanabilir (Arslan \& Yaşar, 2007) çünkü değerler, bilinçli veya bilinçsiz olarak hayatımızın her yönünü etkiler, atılacak adımların, verilecek kararların ve tepkilerin niteliğini bile belirler (UNESCO, 2005). Rokeach (1973) ve Güngör (2000)'e göre değerler, belirli bir davranışın ya da herhangi bir şeyin tercih edilebilir veya edilemez olduğu yönündeki kalıcı inançlardır. Özensel (2003, 219)'e göre de “Bir toplumdaki iyi-kötünün belirlenmesi, ideal düşünme ve davranma yollarının tamamı değerler tarafindan oluşturulur." $\mathrm{Bu}$ yüzden, değerlerin eğitimdeki önemi daha da belirginleşmektedir.

Kirschenbaum (2000), Bolay (2007), Hükelekli ve Gündüz (2007)’e göre değerlerin insanlar tarafından iyi benimsenmesi ve yaşanabilmesi için bilhassa çocuklara kazandırılması gerekir. Bunda aile, okul ve çevre çok büyük rol oynamaktadır. Okullar, ailede kazanılan değerlerin daha da pekiştirileceği ve bazı yeni değerlerin kazanılacağı ortamlardır. Ailede olduğu gibi okulda da değerler eğitiminin yaşantıların bir parçası hâline getirilerek verilmesi en uygun yoldur. Bu yol; öğretmeyi, model olmayı, karakter özelliklerini teşhis etmeyi, ahlâki erdemleri, toplumsal değerleri ve ortak geleceğe bağlı olunan bir sorumluluk anlayışıla kendini yönlendirmeyi kapsamalıdir.

Eğitimde birtakım olay ve olgulara olumlu veya olumsuz duyguların geliştirilmesi, toplum ve devlet tarafından istenilen değerlerin nesillere aktarılması hedeflenir. Ancak modern eğitim sisteminin bilgi ve becerilere aşırı önem vermesi değerlerin ihmaline yol açmıştır. Bu eğitim sisteminin ürünü, olgun ve duygusal olarak dengeli olamayabilen ama zeki ve bilgili olan bir bireydir. Her zaman dürüst ve sorumluluk sahibi olamayabilen ama işini iyi yapan becerikli bir bireydir. Sosyal yetkinliğin gelişimi, iş etiği, teknolojik ve girişimcilik becerilerinin yanı sıra sorumluluklarını bilen vatandaşlar yetiştirmek için insanî değerleri ve standartları vermek de çok önemlidir (Bacanlı, 2006, Ekşi, 2003; UNESCO, 2005).

Uzmanlar, karakterin şekillendirilmesine ilişkin çalışmalar yapılması gerektiğini düşünmektedirler. Ancak çoğunlukla kullanılan kaynaklar ve materyaller öğrencilerin düzeyinde olmamakta ya da öğretilen bilgiler öğrencilerin düşünce sistemine uymamaktadır. Oysa kazandırılacak ilke ve hareketler, çocuğun anlayışı ve yapısıyla 
tutarlı olduğu zaman gelişme daha hızlı olur. Eğer tutarsızlık varsa güvensizlik oluşur ve ilerleme kaydedilemez (Davis, 2006; Sims, 2003).

Günümüzde değerlerin tutarlı bir şekilde nasıl kazandırılması gerektiği ile ilgili birçok eğitim yaklaşımından söz edilmektedir. Bu yaklaşımlardan en sık kullanılanları; değerlerin gizli öğretimi (örtük program) yaklaşımı, değer aktarma (değerlerin doğrudan öğretimi) yaklaşımı, değer açıklama (değer belirginleştirme) yaklaşımı, değer analizi yaklaşımı, ahlâki muhakeme (ahlâki ikilem / ahlâki gelişim) yaklaşımı ve bütüncül yaklaşım: Kolhberg'in adil topluluk okulları yaklaşımıdır (Akbaş, 2004; Doğanay, 2007; Kim-Suh \& Traiger, 1999; Lovat, 2006).

Ling (1998) ise değerlerin tutarlı bir şekilde nasıl kazandırılması gerektiğini şöyle açıklamıştır: "Eğitimde verilmesi gereken değerler kültürlere bağlı olmalıdır çünkü müfredatın hiçbir yönü kültürel bir boşlukta öğretilemez. Bu yüzden okullarda öğretilmesi gereken değerler bir ülkeden diğerine farklılıklar gösterebilir (s. 29).” Bu bağlamda yeni nesle değerler eğitiminin etkili bir biçimde verilebilmesinde toplumun kültürel ögelerinden faydalanılması en doğru yol olarak görülmektedir.

Kültürel ögeler ise varlığını, nesilden nesile aktarılırsa devam ettirirler. Bir toplumun kültürünün ve değerlerinin nesilden nesile aktarılmasında ise sözlü ve yazılı anlatım türleri çok önemli bir yere sahiptir. Sözün yazıdan önce var olması halk anlatımlarının yazılı anlatım türlerinden önce doğmasını sağlamıştır. Halk anlatımları, vücut buldukları halkın duygu ve düşüncelerini, hayata bakış açılarını ve en önemlisi de değerlerini barındıran bir kaynaktır. Bu kaynaklar iyi değerlendirildiklerinde gelecek nesiller üzerinde derin izler bırakabilirler. Halk anlatımlarının başında da masallar, destanlar, efsaneler, halk hikâyeleri ve fikralar gelmektedir. Bu nedenle çalışmanın konusunu da masalların çocukların değerleri üzerindeki etkisi oluşturmuştur çünkü Dilek (2007)’e göre masallar, çocukların ilgisini çekecek her türlü özelliğe sahiptirler. $\mathrm{Bu}$ nedenle çocuğun eğitiminde çocuğa kazandırılmak istenenler masal aracılığıyla rahatlıkla verilebilirler. Masal onu dinleyenlere bir sonuca varma imkânı da verir. Masallarda her zaman zengine karşı yoksul, kötüye karşı iyi kazanır. Dolayısıyla dinleyiciye iyi ve ahlâklı olması telkin edilir.

Masallar, çocukluk yıllarında annelerden, ninelerden, kısacası büyüklerden özellikle akşamları dinlenilen, belleklerde ipek bir kumaş içerisinde saklanan kültür hazineleridir. Onlarda aklı, saflığı, iyiliği, kötülüğü, bizi biz yapan insani değerler bütününü bulunabilir. Kitle iletişim araçlarının fazla yaygınlaşmadığı dönemlerde anlatılması birkaç gece süren masallar, hoşça vakit geçirmek için tek araçtır. Usta anlatıcının etrafina oturan dinleyiciler, bir taraftan işlerini yaparlarken diğer taraftan Zümrüdüanka'nın sırtında masal dünyasına doğru süzülürler; bazen yedi başlı ejderha ile savaşırlar; bazen de padişahın güzel kızına kavuşmak için türlü sınavlara girerler (Kayabaşı, 2008; Sakaoğlu ve Alptekin, 2005). Aşağıda sözlü anlatımın önemli bir ögesi olan masal ve masalın işlevi ile ilgili açıklamalara kısaca yer verilmiştir.

Masallar; insanın gerçekle gerçek üstünü harmanlayıp, olmasını hayal ettiği dünyada, geçmişte belirsiz bir zamanda, sıradan insanların çoğu kez gerçeküstü güçlerle donanıp olağan veya olağanüstü varlık ve olaylarla mücadelesinin anlatıldığ 
hikâyelerdir. Masal; sesin, kelimelerin sihirle güç kazandığı; yer altı ve yer üstü dünyalarının iç içe girdiği, buralarda yaşayanların başından geçenlerin hikâye edildiği; "Keşke...olsaydı." cümlesindeki boşluğun doldurulduğu bir anlatımdır. Bu bağlamda, çocuğun iç dünyası masaldaki hayal dünyasına çok benzediği için çocuk masaldaki olağanüstü durumları yadırgamamakta ve bunları kendisine kolayca mal edebilmektedir (Bilkan, 2001; Dilek, 2007). Böylece çocuk masalın kendisine verdiği iletiyi yadırgamamakta ve hayatında uygulamaktadır.

Masalların birçoğu yoksulla zengin, güçlüyle zayıf, kötüyle iyi ve güzelle çirkinin mücadelesi üzerine kurulduğu için toplumsal kabullerin ve değerlerin araştırılmasında önemli malzemeler içerir (Dilek, 2007). Bu yüzden çocuğa geçmişiyle ilgili bilgiler verdiği gibi millî eğitimin temel amaçları doğrultusunda birçok değeri de kendine has bir şekilde öğretmektedir. Masallar sayesinde çocuk kuru bir bilgi olarak karşısına çıkan iyilik ve kötülüğü, yardımseverliği, hoşgörüyü, arkadaşlığı vb. değerleri daha aktif bir biçimde öğrenmekte ve hayatında uygulamaktadır. Bu araştırmada da Türk toplumunun önemli bir kültürel ögesi olan Türk halk masallarından faydalanılarak değer eğitimi yöntemlerine uygun olarak geliştirilen etkinliklerin, ilköğretim 8. sınıf öğrencilerinin sorumluluk, dostluk/arkadaşlık, barış, saygı, hoşgörü ve dürüstlük gibi insani değerleri üzerindeki etkisi araştırılmak istenmiştir.

\section{Amaç}

$\mathrm{Bu}$ çalışmada, Türk halk masallarından faydalanılarak değerler eğitimi yöntemlerine uygun olarak geliştirilen etkinliklerin, ilköğretim 8. sınıf öğrencilerinin bazı insani değerlere (sorumluluk, dostluk/arkadaşlık, barış, saygı, hoşgörü ve dürüstlük) yönelik tutumları üzerindeki etkisinin belirlenmesi amaçlanmıştır.

$\mathrm{Bu}$ amaç doğrultusunda şu sorulara cevap aranmıştır:

1. İlköğretim 8. sınıf Türkçe dersinde, Türk halk masallarından faydalanılarak değerler ĕgitimi yöntemlerine uygun olarak geliştirilen etkinliklerin uygulandiğı deney grubu ögrencileri ile yürürlükte olan programın uygulandiğı kontrol grubu ögrencilerinin insani değerlere ilişkin tutumları arasında deney grubu lehine anlamlı bir fark var midır?

2. Illköğretim 8. sinıf Türkçe dersinde, Türk halk masallarından faydalanılarak değerler ĕgitimi yöntemlerine uygun olarak geliştirilen etkinliklerin uygulandı̆̆ deney grubu öğrencileri ile yürürlükte olan programın uygulandiğı kontrol grubu ögrencilerinin grup içi insani değerlere ilişkin tutumlarında uygulama öncesi ve uygulama sonrasinda anlamlı bir fark var midir?

\section{Yöntem}

\section{Araştırmanın Deseni (Modeli)}

Araştırmada, Türk halk masallarından faydalanılarak değerler eğitimi yöntemlerine uygun geliştirilen etkinliklerin İlköğretim 8. sınıf Türkçe dersinde uygulama sürecine katılan öğrencilerle, bu sürece katılmayan öğrencilerin bazı insani 
değerlere (sorumluluk, dostluk/arkadaşlık, barış, saygı, hoşgörü ve dürüstlük) yönelik tutumları arasındaki farkı ortaya koymak amaciyla ön-test - son-test kontrol gruplu deneme modeli kullanılmıştır. Bu modelde, Türk halk masallarından faydalanılarak değerler eğitimi yöntemlerine uygun geliştirilen etkinlikler sadece deney grubunda uygulanmıştır. Kontrol grubuna ise bu süre içerisinde 8. sınıf Türkçe öğretim programı içerisinde yer alan etkinlikler dışında herhangi bir etkinlik uygulanmamıştır. Her iki gruba da deneysel işlemden önce ve sonra Dilmaç (2007) tarafından geliştirilen İnsani Değerler Ölçeği ön-test ve son-test olarak uygulanmıştır.

\section{Çalışma Grubu}

Araştırma, 2011-2012 eğitim-öğretim yılının ikinci döneminde Aksaray İl Milli Eğitim Müdürlügüne bağlı bir ilköğretim okulunda öğrenim görmekte olan 8/A sınıfi öğrencileri (20 öğrenci) ile 8/C sınıfı öğrencileri (22 öğrenci) ile yapılmıştır. Yansız atama yöntemiyle, bu sınıflarda derse giren iki öğretmene kura çektirilerek, 8/C sınıfi deney grubu, 8/A sınıfı ise kontrol grubu olmak üzere belirlenmiştir. Grupların denkliklerinin belirlenmesi amacıyla İnsani Değerler Ölçeği bu okulda bulunan sekizinci sınıfların üçüne de (8/A, 8/B ve 8/C) uygulanmıştır. Sonuçlar incelendiğinde 8/A ve 8/C sınıflarının verilerinin birbirine çok yakın olduğu tespit edilmiştir (8/A ve 8/C sınıflarına ait bu veriler "Bulgular" bölümünde verilmiştir. Gruplar belirlendikten sonra aynı gün içerisinde uygulamaya başlandığı için tekrar bir ön-test uygulamasına gerek duyulmamıştır). Bu yüzden $8 / \mathrm{A}$ ve $8 / \mathrm{C}$ sınıfları çalışma grubu olarak belirlenmiştir.

\section{Uygulama Süreci (Deneysel süreç)}

1. Deney ve kontrol gruplarına İnsani Değerler Ölçeği ön-test olarak eş zamanlı uygulanmiştır.

2. İlköğretim 8. sınıf öğrencilerine masallar serbest okuma saatlerinde okutturulmuştur. Deney grubuna Türk halk masallarından faydalanılarak değerler eğitimi yöntemlerine uygun geliştirilen etkinlikler İlköğretim 8 . sınıf öğrencilerine Türkçe dersi serbest okuma saatlerinde uygulanmıştır. Bu süreçte öncelikle Türk halk masalları sessiz bir şekilde herkese okutturulmuştur. Sonra birkaç iyi okuyucuya sesli bir şekilde okutturulmuştur. Daha sonra öğrencilerle masallar üzerine konuşulmuştur (masalın ilgi çekici yönleri, masalda en çok nelerden etkilendikleri, masaldan çıkarılan sonuç, masalın vermek istediği mesaj, masalın ana fikri vb. gibi). $\mathrm{Bu}$ süreçten sonra öğrenenlerin kendi değerlerini doğru bir şekilde belirlemelerine, bu değerler üzerinde düşünmelerine ve değerlerini davranışa dönüştürmelerine yardımcı olmak amacıyla değerler eğitimi ile ilgili "Değerlerin Açıklanması", "Değer Analizi" ve "Ahlâki Muhakeme" gibi yaklaşımlardan faydalanılarak hazırlanmış birtakım sorular yöneltilmiştir. Ek - 1'de araştırmanın deneysel sürecinde uygulanan bir etkinlik örneği sunulmuştur. Diğer etkinlikler de bu etkinliğe benzer bir şekilde hazırlanmıştır. Uygulama sürecinde işlenen Türk halk masalları: Ayı ile Üç 
Kurdun Arkadaşlı̆̆ı, Kurt ile Kaplumbağa (Alay, 2005); Horoz ile Bey Oğlu, Tamâhkar Antikacı (Bakırcı, 2006); Üç Kardeşler, Gökbulut, Kötü Kral, Yedi Çingene (Helimoğlu Yavuz, 2002); Dev Anası ve Keloğlan (Alangu, 2009).

3. Uygulama süreci, 8 hafta sürmüştür. Her hafta bir etkinlik uygulanmıştır. Ön-test ve son-test araştırmacılar tarafından uygulanmış; etkinlikler ise derse giren Türkçe öğretmeni tarafından uygulanmıştır.

4. Kontrol grubuna Türk halk masallarından faydalanılarak değerler eğitimi yöntemlerine uygun olarak geliştirilen etkinliklerle ilgili herhangi bir işlem yapılmamıştır. Sadece 8. sınıf Türkçe öğretim programında yer alan etkinlikler uygulanmıştır. Her iki grubun da Türkçe derslerine aynı öğretmen girmiştir.

5. Deney ve kontrol gruplarına İnsani Değerler Ölçeği son test olarak eş zamanlı uygulanmıştır.

\section{Veri Toplama Aracı}

$\mathrm{Bu}$ araştırmada, öğrencilerin insani değerlerini belirlemede Dilmaç (2007) tarafından geliştirilen "İnsani Değerler Ölçeği (İDÖ)” (Sayın Doç.Dr. Bülent DİLMAÇ’tan izin alınarak) kullanılmıştır. Ölçekte insani değerler, “Sorumluluk, Dostluk/Arkadaşlık, Barışçı olma, Saygı, Hoşgörü ve Dürüstlük” olmak üzere altı boyutta toplam 42 madde ile ölçülmektedir. Bu ölçek bireysel veya gruplar hâlinde uygulanabilen Likert tipi bir ölçektir. Ölçekteki maddeler beşli Likert tipi (1: Hiçbir Zaman, 2: Nadiren, 3: Arasıra, 4: S1k Sık, 5: Her Zaman) bir dereceleme ölçeği şeklinde ifade edilmiştir. Araştırmacı, ölçeğin geliştirilmesi aşamasında 322 öğrenciden elde edilen verilerle geçerlik ve güvenirlik analizlerinin gerçekleştirildiğini belirtmektedir. Ölçekte yapı geçerliği için faktör analizi yapılmış ve bu işlem sonucunda yedişer maddeden oluşan altı faktörlü bir ölçek oluşturulmuştur. Bu faktörler, Sorumluluk (yedi madde), Dostluk/Arkadaşlık (yedi madde), Barışçı Olma (yedi madde), Saygı (yedi madde), Hoşgörü (yedi madde), Dürüstlük (yedi madde) şeklinde isimlendirilmiştir. Ölçeğin güvenirlik çalışması için ise iç tutarlılık katsayıları (Cronbach Alpha)'nın hesaplandığı belirtilmiştir. Bu süreçte ölçekteki altı faktör ayrı ayrı analize tabi tutulmuştur. Sonuç olarak 42 maddelik tüm ölçeğin iç tutarlılık katsayısı alfa. 92 bulunmuştur. Bu işlemden sonra ölçeğin kararlılık anlamındaki güvenirliği için ölçek, 150 öğrenciden oluşan bir gruba 20 gün ara ile iki kez uygulanarak test-tekrar test yöntemiyle güvenirlik katsayıları hesaplanmıştır. Bu süreçte ise ölçeğin tümü için kararlılık katsayısı .87 bulunmuştur.

Dilmaç (2007) tarafından ortaöğretim düzeyindeki öğrenciler için geliştirilen “İnsani Değerler Ölçeği”nin geçerlik ve güvenirlik çalışmaları incelendiğinde ölçeğin yeterli derecede geçerlik ve güvenirliğe sahip olduğu görülmektedir. Ancak bu çalışmada ölçeğin ilköğretim 8. sınıf öğrencilerine uygulanması kararlaştırılmıştır. Bu yüzden Dilmaç (2007) tarafından ortaöğretim düzeyindeki öğrenciler için geliştirilen “İnsani Değerler Ölçeği’”ne 8. sınıf düzeyinde tekrar bir güvenirlik çalışması yapılmasına karar verilmiştir. Bu süreçte ölçek, 169 sekizinci sınıf öğrencisine 
uygulanmış ve elde edilen verilerden ölçeğin güvenirliğini ölçmek için iç tutarlılık katsayıları (Cronbach Alpha) hesaplanmıştır. Sonuç olarak 42 maddelik tüm ölçeğin iç tutarlılık katsayısı .77 bulunmuştur. Bu sonuç, ölçeğin sekizinci sınıf öğrencileri için de yeterli derecede güvenirliğe sahip olduğunu göstermektedir.

\section{Verilerin Analizi}

Deney ve kontrol gruplarının ön-test ve son-test puanları elde edildikten sonra gruplar arası ve grup içi karşılaştırmalarda ilişkisiz örneklemler $t$ testinden yararlanılmış ve anlamlılık düzeyi olarak .05 belirlenmiştir. Bu süreçte, altı alt boyuttan (faktörden) oluşan İnsani Değerler Ölçeğinin, öğrencilerin insani değerlere yönelik tutumlarının bir bütün olarak ele alınması gerektiği düşüncesiyle, 42 maddenin tamamı tek boyut hâlinde analize tâbi tutulmuştur. Veriler SPSS 15 (Statistical Package for Social Sciences) programı kullanılarak analiz edilmiştir.

\section{Bulgular}

1. İlköğretim 8. sınıf Türkçe dersinde Türk halk masallarından faydalanılarak değerler ĕgitimi yöntemlerine uygun olarak geliştirilen etkinliklerin uygulandiğ deney grubu ögrrencileri ile yürürlükte olan programın uygulandiğg kontrol grubu ögrencilerinin insani değerlere ilişkin tutumları arasında deney grubu lehine anlamlı bir fark var mıdır? sorusuna cevap aramak amacıyla İnsani Değerler Ölçeği deney ve kontrol grubu öğrencilerine deneysel işlem öncesinde ve sonrasında ön-test ve son-test olarak uygulanmıştır.

Uygulanan test sonuçlarına göre deney ve kontrol gruplarının İnsani Değerler Ölçeğinden aldıkları ön-test puanlarıyla ilgili bulgular Tablo 1'de gösterilmiştir.

Tablo 1

Deney ve Kontrol Gruplarının İnsani Değerler Ölçeğinden Aldıkları Ön-Test Puanlarına İlişkin Bulgular

\begin{tabular}{lcccccc}
\hline Grup & $N$ & $\bar{X}$ & $S$ & $S d$ & $t$ & $p$ \\
\hline Deney & 22 & 3.23 & .457 & 40 & .835 & .409 \\
Kontrol & 20 & 3.13 & .328 & & & \\
\hline$p>0.05$ & & & & &
\end{tabular}

Tablo 1'den anlaşılacağı üzere, deneysel işlem öncesi deney ve kontrol grubunda yer alan öğrencilerin, İnsani Değerler Ölçeğinin ön-testinden elde ettikleri ortalama puanlar arasında deney grubu lehine 0.1 puanlık bir fark vardır. Bu farkın anlamlı olup olmadığı .05 anlamlılık düzeyinde $t$ testi ile test edildiğinde, $t$ değeri $.835[t(40)=.835$, $p>.05$ ] bulunmuştur. Bu sonuca göre deney ve kontrol grubunda yer alan öğrencilerin insani değerlere ilişkin deneysel işlem öncesi tutumları arasında anlamlı bir fark yoktur. 
Bu ön-test sonuçlarından sonra, Türk halk masallarından faydalanılarak değerler eğitimi yöntemlerine uygun geliştirilen etkinliklerin etkililiğini gözlemlemek amacıyla her iki grupta yer alan deneklerin son-test puan ortalamaları arasında anlamlı bir fark olup olmadığına bakılmıştır. Deney ve kontrol gruplarının İnsani Değerler Ölçeğinden aldıkları son-test puanlarıyla ilgili bulgular Tablo 2'de gösterilmiştir.

Tablo 2

Deney ve Kontrol Gruplarının İnsani Değerler Ölçeğinden Aldıkları Son-Test Puanlarına İlişkin Bulgular

\begin{tabular}{lccccc}
\hline Grup & $N$ & $\bar{X}$ & $S$ & $S d$ & $t$ \\
\hline Deney & 22 & 4.21 & .239 & 40 & $8.899 *$ \\
Kontrol & 20 & 3.50 & .279 & & \\
$* p<.05$ & & & & &
\end{tabular}

Tablo 2'den anlaşılacağı üzere, deney grubundaki öğrencilerle kontrol grubundaki öğrencilerin, İnsani Değerler Ölçeğinin son-testinden elde ettikleri ortalama puanlar arasında deney grubu lehine 0.71 puanlık bir fark vardır. Bu farkın anlamlı olup olmadığı .05 anlamlılık düzeyinde $t$ testi ile test edildiğinde, $t$ değeri $8.899[t(40)=8.899$, $p<.05$ ] bulunmuştur. Bu sonuç, Türk halk masallarından faydalanılarak değerler eğitimi yöntemlerine uygun geliştirilen etkinliklerin uygulandığı deney grubu öğrencileri ile yürürlükte olan programın uygulandığı kontrol grubu öğrencilerinin tutumları arasında deney grubu lehine anlamlı bir fark olduğunu göstermektedir.

2. İlköğretim 8. sinıf Türkçe dersinde, Türk halk masallarından faydalanılarak

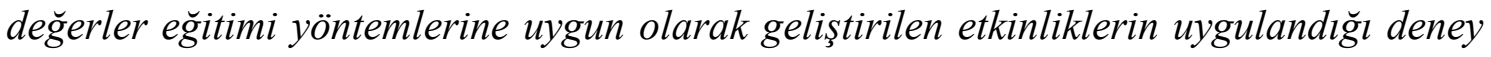
grubu ögrrencileri ile yürürlükte olan programın uygulandiğg kontrol grubu ögrencilerinin grup içi insani değerlere ilişkin tutumlarında uygulama öncesi ve uygulama sonrasında anlamlı bir fark var mıdır? sorusuna cevap aramak amaciyla deney ve kontrol grubu öğrencilerinin ön-test ve son-test puanları arasında grup içi karşılaştırma yapılmıştır.

Kontrol grubu öğrencilerinin ön-test ve son-test puanlarının karşılaştırılması ile ilgili bulgular Tablo 3 'te gösterilmiştir. 
Tablo 3

Kontrol Grubu Öğrencilerinin İnsani Değerler Ölçeğinden Aldıklarl Ön-Test ve SonTest Puanlarına İlişkin Bulgular

\begin{tabular}{lccccc}
\hline Grup & $N$ & $\bar{X}$ & $S$ & $S d$ & $t$ \\
\hline Ön-test & 20 & 3.13 & .328 & 38 & $3.835^{*}$ \\
Son-test & 20 & 3.50 & .279 & & \\
\hline
\end{tabular}

$* p<.05$

Tablo 3'ten anlaşılacağı üzere, kontrol grubunda yer alan öğrencilerin, İnsani Değerler Ölçeğinin ön-test ve son-testinden elde ettikleri ortalama puanlar arasında sontest puanları lehine 0.37 puanlık bir fark vardır. Bu farkın anlamlı olup olmadığ .05 anlamlılık düzeyinde $t$ testi ile test edildiğinde, $t$ değeri $3.835[t(38)=3.835, p<0.05]$ bulunmuştur. $\mathrm{Bu}$ sonuç, yürürlükte olan programın uygulandığı kontrol grubu öğrencilerinin İnsani Değerler Ölçeğinin ön-test ve son-testinden aldıkları puanlar arasında son test puanları lehine anlamlı bir fark olduğunu göstermektedir.

Deney grubu öğrencilerinin ön-test ve son-test puanlarının karşılaştırılması ile ilgili bulgular Tablo 4'te gösterilmiştir.

Tablo 4

Deney Grubu Öğrencilerinin İnsani Değerler Ölçeğinden Aldıkları Ön-Test ve Son-Test Puanlarına İlişkin Bulgular

\begin{tabular}{lccccc}
\hline Grup & $N$ & $X^{-}$ & $S$ & $S d$ & $t$ \\
\hline Ön-test & 22 & 3.23 & .457 & 42 & $8.902^{*}$ \\
\hline Son-test & 22 & 4.21 & .239 & & \\
${ }^{*} p<.05$ & & & & &
\end{tabular}

Tablo 4'ten anlaşılacağı üzere, deney grubunda yer alan öğrencilerin, İnsani Değerler Ölçeğinin ön-test ve son-testinden elde ettikleri ortalama puanlar arasında sontest puanları lehine 0.98 puanlık bir fark vardır. Bu farkın anlamlı olup olmadığ 0.05 anlamlılık düzeyinde $t$ testi ile test edildiğinde, $t$ değeri $8.902[t(42)=8.902, p<0.05]$ bulunmuştur. $\mathrm{Bu}$ sonuç, Türk halk masallarından faydalanılarak değerler eğitimi yöntemlerine uygun geliştirilen etkinliklerin uygulandığı deney grubu öğrencilerinin İnsani Değerler Ölçeğinin ön-test ve son-testinden aldıkları puanlar arasında son-test puanları lehine anlamlı bir fark olduğunu göstermektedir.

\section{Sonuç ve Tartışma}

Araştırma bulguları incelendiğinde, ön-test ve son-test grup içi analiz verilerine göre Türk halk masallarından faydalanılarak değerler eğitimi yöntemlerine uygun geliştirilen etkinliklerin de yürürlükte olan programdaki etkinliklerin de, ilköğretim 8. 
sınıf öğrencilerinin insani değerlere yönelik tutum puanlarını anlamlı bir şekilde yükselttiği görülmektedir. Ancak gruplar arası karşılaştırmada, Türk halk masallarından faydalanılarak değerler eğitimi yöntemlerine uygun geliştirilen etkinliklerin ilköğretim 8. sınıf öğrencilerinin insani değerlere yönelik tutum puanlarını yürürlükte olan programa göre daha anlamlı bir biçimde yükselttiği görülmüştür. Bu durum, Türk halk masallarından faydalanılarak değerler eğitimi yöntemlerine uygun olarak geliştirilen etkinliklerin yürürlükte olan programa göre öğrencilerin insani değerlere yönelik olumlu tutum geliştirmelerinde daha etkili olduğu şeklinde yorumlanabilir.

Literatürde değerler eğitimine yönelik geliştirilen etkinliklerin öğrencilerin ilgili konuya yönelik tutumlarını olumlu yönde etkilediğini destekleyen çalışmalar bulunmaktadır. Aktepe (2010), ilköğretim 4. sınıf sosyal bilgiler dersinde yardımseverlik değerinin etkinlik temelli öğretiminin öğrencilerin tutumlarına etkisini incelemiştir. Uygulama sonucunda elde edilen verilere göre deney grubundaki öğrencilerin, kontrol grubundaki öğrencilere göre, yardımseverliğe yönelik tutum puanlarının anlamlı düzeyde yüksek olduğu belirtilmiştir. Meaney (1979) ilköğretim öğrencilerine benlik değerlerinin kazandırılmasına yönelik değerler eğitimi etkinliklerini altı hafta uygulamıştır. Sonuç olarak öğrencilerin; özsaygılarına, duygusal, entelektüel ve fiziksel bakımdan gelişim potansiyellerine, ailesine, arkadaşlarına, daha büyük kişilere, etnik gruplara, engelli insanlara, Amerikan büyüklerine, anayasal haklara ve sorumluluklara, vatanseverliğe, doğal çevrenin korunmasına, estetik anlayışa ve aç insanlara yönelik davranışlarında ve tutumlarında olumlu yönde değişiklikler gözlenmiştir. Bunun yanı sıra birçok araştırma sonuçlarında da (Aladağ, 2009; Balc1, 2008; Demirtaş, 2009; Dilmaç, 2007; Keskinoğlu, 2008; Koç, 2007) değerler eğitiminin uygulamalı bir biçimde verildiği takdirde öğrencilerde ilgili değerlere yönelik olumlu tutum veya davranış geliştirmede daha etkili olduğu ortaya konmaktadır.

Yukarıdaki araştırmaların bulguları da göz önünde bulundurulduğunda değerler eğitimine ilişkin geliştirilecek etkinliklerin öğrencilerin ilgili değer ya da değerlere yönelik olumlu tutum geliştirmelerinde yürürlükte olan programa göre daha etkili olacağını söylemek mümkündür. Ancak, öğrencilerin değerlere yönelik olumlu tutum geliştirmelerine dayanılarak bu değerleri kazandıklarını söylemek doğru olmaz çünkü tutumların yanı sıra insanların değerlerini gösteren birçok özellikleri vardır. Bu özellikler, Raths, Harmin ve Simon (1978, ss. 31-58) tarafindan değer göstergeleri olarak ifade edilmiştir: "Bu değer göstergeleri davranışta, bir değerin varlığını gösteren fakat değer olmayan ifadelerdir. Değer göstergeleri sekiz kategoriden oluşmaktadır. Bu sekiz kategori; hedefler ve amaçlar, istekler, duygular, ilgiler, inançlar ve görüşler, davranışlar, etkinlikler ve endişelerdir." Öğrencilere bir değerin kazandırılıp kazandırılmadığını ortaya koymak isteyen araştırmacıların değer göstergelerinin tamamını ortaya koyacak ölçme araçları geliştirerek uygulanan etkinliklerin ilgili değerlerin kazandırılması yönündeki etkililiğini sınamaları daha doğru ve güvenilir bir yol olacaktır. Oysa, Raths, Harmin ve Simon (1978) tarafindan belirlenen bu göstergeler çoğunlukla sınıf içinde ortaya çıkmamaktadır. Bu yüzden değer kazandırmaya yönelik 
geliştirilen ve uygulanan etkinliklerin etkililiğini tam anlamıyla ölçmek oldukça zor görünmektedir.

$\mathrm{Bu}$ açıklamalara bakıldığında değerlere yönelik verilen eğitimin sonuçlarının nasıl ölçüleceği önemli bir sorun olarak görülmektedir. Hawkes ve Heppenstall (2002)’ye göre değer eğitiminin sonuçlarını ölçmek kolay değildir fakat öğrencilerin toplumda ve okulda pozitif davranışlarının yaygınlaşması değer eğitiminin etkili olduğunun göstergesi olarak algılanabilmektedir. Yapıcı ve Zengin (2003)'e göre ise değerler üzerinde çalışmanın çeşitli zorlukları vardır çünkü değerlerin tanımlanmasından sınıflandırılmasına, değerleri araştırırken nasıl bir yol ve yöntem takip edileceğinden elde edilen sonuçlara ne derece güvenileceğine kadar pek çok hususta ciddi tartışmalar devam etmektedir. Ancak bireylerin dünya görüşlerini belirlemeye hizmet eden değerlerin çok çeşitli yaklaşımlarla incelenmesi, en azından hem mevcut tutum ve davranışlarını anlamaya, hem de gelecekte ne tür davranışlarda bulunacaklarını öngörebilmeye imkân vermektedir.

Araştırmanın sonuçlarına göre Türk halk masallarından faydalanılarak değerler eğitimi yöntemlerine uygun geliştirilen etkinliklerin ilkögretim 8. sınıf öğrencilerinin insani değerlere yönelik tutumları üzerinde yürürlükte olan programa göre daha etkili olduğu görülmüştür. Bu bağlamda Türk halk masalları çalışmamızda olduğu gibi veya farklı yöntemlerle değerler eğitiminde uygulanabilir. Ancak, bu çalışmada Türk halk masallarından faydalanılarak geliştirilen etkinliklerin sadece öğrencilerin insani değerlere yönelik tutumları üzerindeki etkisine bakılmıştır. Yukarıda da belirtildiği gibi bir değerin kazandırılıp kazandırılmadığının ölçülmesinde tutumların belirlenmesi tek başına yeterli görülmemektedir. Bu yüzden Türk halk masallarından faydalanılarak değerler eğitimi verilmesine yönelik yapılacak çalışmalarda, bu çalışmadaki etkinliklere benzer etkinlikler tasarlanarak, diğer değer göstergelerini de ayrı ayrı veya birlikte ele alacak ölçme araçlarının geliştirilerek kullanılması önerilir. Bu sayede kültürün önemli bir parçası olan halk masallarının çocuklara değerlerin kazandırılması üzerindeki etkisi açıkça ortaya konmuş olacaktır.

\section{Kaynakça}

Akbaba-Altun, S. (2003). Eğitim yönetimi ve değerler. Değerler Eğitimi Dergisi, 1(1), 7-18.

Akbaş, O. (2004). Türk milli eğitim sisteminin duyuşsal amaçlarının ilköğretim II. kademedeki gerçekleşme derecesinin değerlendirilmesi (Yayımlanmamış doktora tezi). Gazi Üniversitesi, Ankara.

Aktepe, V. (2010). İlkögrretim 4. Sınıf sosyal bilgiler dersinde "yardımseverlik" değerinin etkinlik temelli öğretimi ve öğrencilerin tutumlarına etkisi (Yayımlanmamış doktora tezi). Gazi Üniversitesi, Ankara.

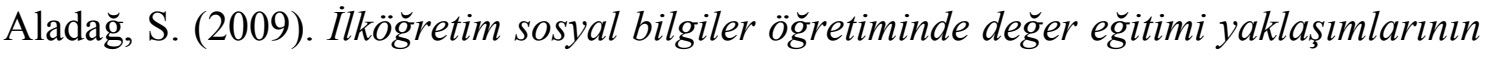
ögrencilerin sorumluluk değerini kazanma düzeyine etkisi (Yayımlanmamış doktora tezi). Gazi Üniversitesi, Ankara.

Alangu, T. (2009). Keloğlan masallart. İstanbul: YKY. 
Alay, O. (2005). Bingöl masalları (inceleme-metin) (Yayımlanmamış yüksek lisans tezi). Firat Üniversitesi, Elazı ̆.

Arslan, Z. Ş., \& Yaşar, F. T. (2007). Yükselen değer kavramı üzerine eleştirel bir yaklaşım. Değerler Ĕgitimi Merkezi Dergisi, 1(1), 8-11.

Bacanlı, H. (2006). Duyuşsal davranış eğitimi (3. baskı). Ankara: Nobel Yayın Dağıtım.

Bakırcı, N. (2006). Niğde masalları (araştırma-inceleme-metin). Niğde: Niğde Yüksek Öğrenim Vakfı Yayınları.

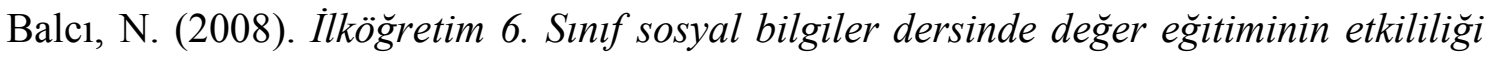
(Yayınlanmamış yüksek lisans tezi). Marmara Üniversitesi, İstanbul.

Bilkan, A. F. (2001). Masal estetiği. İstanbul: Timaş Yayınları.

Bolay, S.H. (2007). Değerlerimiz ve günlük hayat. Değerler Ĕgitimi Merkezi Dergisi, 1(1), 12-19.

Davis, H. D. (2006). Character education in america's public schools. Journal of Church and State. Retrieved from http://www.redorbit.com/news/education/456519/character_education_in_americas publicshs

Demirtaş, S. (2009). Çocuk yuvasında kalan korunmaya muhtaç çocukların değer eğitiminde yaratıcı dramanın etkililiği (Yayımlanmamış doktora tezi). Hacettepe Üniversitesi, Ankara.

Dilek, İ. (2007). Altay masalları. Ankara: Alp Yayınevi.

Dilmaç, B. (2007). Bir grup fen lisesi öğrencisine verilen insani değerler ĕgitiminin insani değerler ölçeği ile sınanması (Yayımlanmamış doktora tezi). Selçuk Üniversitesi, Konya.

Doğanay, A. (2007). Değerler eğitimi. C. Öztürk (Ed.) içinde Hayat bilgisi ve sosyal bilgiler öğretimi yapılandırmacı bir yaklaşım (3. baskı, ss. 255-286). Ankara: PegemA Yayıncilık.

Ekşi, H. (2003). Temel insani değerlerin kazandırılmasında bir yaklaşım: Karakter eğitimi programları. Değgerler Ĕ̈itimi Dergisi, 1(1), 79-96.

Güngör, E. (2000). Değerler psikolojisi üzerine araştırmalar (3. bask1). İstanbul: Ötüken Yayınları.

Hawkes, N., \& Heppenstall, L. (2002). Living values - one primary school's way of encouraging a values-based education. Retrieved from www.rcpsych.ac.uk/PDF/nl9five

Helimoğlu Yavuz, M. (2002). Masallar ve eğitimsel işlevleri. Ankara: Kültür Bakanlı̆̆ Yayınları.

Hökelekli, H., \& Gündüz, G. (2007). Üstün yetenekli çocukların değer yönelimleri ve eğitimleri. R. Kaymakcan, S. Kenan, H. Hökelekli, Ş. Arslan ve M. Zengin (Ed.) içinde Değerler ve Eğitimi Uluslararası Sempozyumu Bildiriler Kitabı (1.baskı, ss. 371-396). İstanbul: Dem Yayınları. 
Kayabaşı, O. A. (2008). Anamur folkloru (Yayımlanmamış yüksek lisans tezi). Selçuk Üniversitesi, Konya.

Keskinoğlu, M. Ş. (2008). İlköğretim beşinci sınıf öğrencilerine uygulanan mesnevi temelli değerler ĕgitimi programının ahlaki olgunluğa ve saldırganlık eğilimine etkisi (Yayınlanmamış yüksek lisans tezi). Yeditepe Üniversitesi, İstanbul.

Kim-Suh, B., \& Traiger, J. (1999). Teaching values through elementary social studies and literature curricula. Education, 119(4), 723-729. Retrieved from http://www.questia.com

Kirschenbaum, H. (2000). From values clarification to character education: A personal journey. Journal of Humanistic Counseling, Education and Development, 39(1), 420. Retrieved from ERIC database. (EJ617563)

Koç, K. (2007). İlköğretim 7. Sinıflarda okutulan vatandaşlık ve insan hakları ĕgitimi dersinde öğrenciye kazandırılması amaçlanan evrensel değerlere ilişkin tutumlar üzerinde öğretim sürecinin etkisi (Yayımlanmamış yüksek lisans tezi). Fırat Üniversitesi, Elazığ.

Köylü, M. (2007). Küresel bağlamda değerler eğitimine duyulan ihtiyaç. R. Kaymakcan, S. Kenan, H. Hökelekli, Ş. Arslan ve M. Zengin (Ed.) içinde Değerler ve Eğitimi Uluslararası Sempozyumu Bildiriler Kitabı (1. baskl, ss. 287-311). İstanbul: Dem Yayınları.

Ling, P. (1998). Investigating values in education. In J. Stephenson, L. Ling, E. Burman, \& M. Cooper (Eds.), Values in education (pp. 20-31). London and New York: Routledge.

Lovat, T. (2006). Values education and 'doing well' in school. Retrieved from www.valuesineducation. org.aupdflovat061026.pdf

Meaney, M. H. (1979). A guide for implementing values education in the primary grades (Unpublished doctoral dissertation). Seattle University, Seattle, Washington.

Özensel, E. (2003). Sosyolojik bir olgu olarak değer. Değerler Eğitimi Dergisi, 1(3), 217-239.

Raths, L. E., Harmin, M., \& Simon, S. B. (1978). Values and teaching: Working with values in the classroom (1st ed.). Columbus, Ohio: Charles E. Merill Company.

Rokeach, M. (1973). The nature of human values. New York: Free Pres.

Sakaoğlu, S., \& Alptekin, A. B. (2005). Türk halk edebiyatı (ders notlarl). Konya.

Sarı, E. (2005). Öğretmen adaylarının değer tercihleri: Giresun Eğitim Fakültesi örneği. Değerler Ĕ̈itimi Dergisi, 3(10), 73-88.

Sims, M. (2003). Value-based education for pre-service students in children and family studies. Journal of Educational Enquiry, 4(1), 68-79. Retrieved from www.literacy.unisa.edu.au/jee/ Papers/JEEVol4No1/Paper\%205.pdf

Tillman, D. (2001). Living values activities for children ages 8-14. Deerfield Beach, Florida: Health Communications Inc. 
United Nations Educational, Scientific and Cultural Organization. (2005). Learning to do: Values for learning and working together in a globalized world. An Integrated Approach to Incorporating Values Education in Technical and Vocational Education and Training. Bonn, Germany: UNESCO-UNEVOC. Retrieved from http://www.unevoc.unesco.org

Veugelers, W., \& Kat, E. (1999, April 19-23). Moral development at home and at school: Division of moral tasks between parents and teachers in secondary school. Paper presented at the Annual Meeting of the American Educational Research Association, Montreal, Quebec, Canada. Retrieved from ERIC database. (ED435490)

Yapıc1, A., \& Zengin, S. Z. (2003). İlâhiyat fakültesi öğrencilerinin değer tercih sıralamaları üzerine psikolojik bir araştırma: Çukurova Üniversitesi İlâhiyat Fakültesi örneği. Değerler Ĕ̆itimi Dergisi, 1(4), 173-206. 


\section{Ek-1}

\section{Etkinlik Planı}

\section{AYI İLE ÜC KURDUN ARKADAȘLIĞI}

Bir zamanlar bir ormanda bir ayıyla üç kurt arkadaş olmuşlar. Bu kurtlar üç ayrı renkteymiş. Kurtlardan biri ak, biri kara, biri de kızıl renkliymiş. Bu ayı ile üç kurt birlikte yaşayıp birlikte yer içerlermiş. Arkadaşlıkları öylece sürüp gidiyormuş. Gel zaman git zaman ormanda avlanacak hayvan bulamaz olmuşlar. Artık karınları eskisi gibi doymuyormuş. Tabii ayı bu durumdan hiç memnun değilmiş. Kurtlardan kurtulmak istiyormuş. Ancak üç kurtla kavgayı da göze alamadığı için onlardan kurtulmak için bir çare düşünmüş. Sonunda kendince bir plan hazırlamıș. Nihayet bir sabah ayı uykusundan yeni uyanmıșken kızıl kurt ile ak kurdun birlikte olduklarını görmüş. Kendi kendine "Oh be. Fırsat bu firsat!” deyip iki kurdun yanına gitmiş ve onlara:

"Dostlarım dün gece bir rüya gördüm. Rüyamda bir ak saçlı ak sakallı bir ihtiyar bana

kısmetinizin kara kurttan kaynaklandığını, kara kurdun kara talihiyle bize uğursuzluk getirdiğini söyledi. Yaa, duydunuz mu?" der.

Ayının anlattığına inanan iki kurt ona dönerek:

"Ee... ne yapabiliriz ki?" diye sorunca ayı:

"Kara kurttan kurtulmalıyız. Ondan kurtulmanın tek yolu da bir firsatını bulup onu öldürmektir. Belki o zaman avımızın bereketi de artmış olur." der.

Ayı ve iki kurt, arkadaşları kara kurdu öldürürler. Kalan iki kurt ile ayının da arkadaşlıkları sürüp gitmiş. Lâkin ayının planında bu iki kurttan da kurtulmak olduğu için aklı onlardaymış. Günlerden bir gün ayı ile ak kurt baş başa kaldıklarında kurda, uğursuzluğun bitmediğini, onun kızıl kurtla devam ettiğini, bu yüzden de ondan kurtulmaları gerektiğini yoksa açlıktan öleceklerini söyler. Ak kurt ayının bu sözüne inanarak ayıyla birlik olup kızıl kurdu öldürmüşler. Ama yine de avlanacak hayvan bulamamışlar. Ayının da sabrı kalmamış, gittikçe asabileşmiş. Bir gün ayı ile ak kurt ormanda avlanmak için gezerlerken ayı, bu kurttan da kurtulmak için bir bahane arıyormuş. İki arkadaş bir dereden su içerlerken ayı bir bahane bulup kurdu yiyecek ya söylenmiş:

"Hey miskin kurt, ben senden daha güçlü daha itibarlı değil miyim? Sen bana nasıl olur da saygısızlık ediyorsun?”

Kurt:

"Ne saygısızlığıymış? Beraberce su içiyoruz ya...” deyince,

Ay1:

"Sen kim oluyorsun da benden yukarıda su içip suyumu bulandırıyorsun? Çekil oradan!” der.

Ak kurt ayıya dönerek:

"Evet efendim. Haklısın tabii(!) Ne zaman ki ben sana inanıp arkadaşlarıma ihanet ettim, işte o zaman asıl ölümü hak etmiştim.” demiş ve cezasını çekmiş.

Benden yalan, Allah'tan doğru; böyle bitmiş bu masalın sonu.

\section{Bölüm: Değerlerin Ortaya Konması ve Analiz Edilmesi}

1. Bu masal okunduktan/okutturulduktan sonra öğrenciler masalla ilgili düşüncelerini açıklamaya davet edilir (Düşüncesini açıklamakta zorlanan öğrenciler, ayının neden böyle bir oyun düşündüğü, kurtların neden bu oyuna geldikleri, ak kurdun neden ölümü hak ettiğini söylediği vb. ifadelerle yönlendirilebilir).

1. Masaldan çıkarılan sonuç, masalın vermek istediği mesaj, masalın ana fikri üzerinde tartışılır.

2. Sizce Ayl'nın değerleri (düşünceleri) nedir? Neye önem veriyor? Neye önem vermiyor?

3. Sizce ayının oyununa gelen kurtların (istenirse kurtlar tek tek sorulabilir) değerleri (düşünceleri) nedir? Neye önem veriyorlar? Neye önem vermiyorlar?

4. Ak kurt iş işten geçtikten sonra aslında neyin değerli olduğunun farkına varıyor?

5. Siz kurtların (ayının oyununa gelenlerin) yerinde olsanız... ayı size böyle bir teklif yaptığında nasıl davranırdınız? Düşünün, ancak düşünürken içinde bulunduğunuz durumun (yiyecek bulamıyorsunuz) kurtlarınki ile aynı olduğunu göz önünde bulundurun. Belli bir düşünme süresinden sonra öğrenciler düşüncelerini sebepleriyle birlikte açıklamaya davet edilir.

6. Bu davranışınız sonunda neler olabilirdi? Bu sonuç/sonuçlar sizi memnun eder mi?

\section{Bölüm: Kendi Yaşamında İlgili Değerler Üzerine Düşünülmesi}

1. Gerçek hayatta benzer bir durumla karşılaştınız mı? (tabiî ki sonunda ölüm olmayan farklı durumlar, birilerinin çıkarı, kıskançlığı vb. herhangi bir durum için sizden arkadaşlarınıza ihanet etmenizi istedi mi? vb. açıklamalar verilir) Eğer karşılaştılırsa, "Bu durum karşısında siz ne yaptınız?” Cevap/cevaplar alındıktan sonra onun cevabı tekrarlanabilir ve "Neden böyle davranmayı tercih ettin?”, Bu davranışının sonuçları ne oldu? Bu sonuç senin için değerli mi? Memnun oldun mu? Neden?

2. Böyle bir olayla veya benzeri bir olaya karşılaşanlar için tekrar karşılaşırsanız, karşılaşmayanlara da sizde bundan sonra karşılaşırsanız: Nasıl davranmayı düşünüyorsunuz? Bu davranışınızın sonuçları sizce ne olabilir? Bu ulaşmayı düşündüğ̈̈nüz sonuç sizi mutlu eder mi? Sizin için değerli mi? Nedenini açıklar 
mısınız? gibi sorular yöneltilir ve düşüncelerini ifade etmeleri için öğrencilere söz hakkı verilir.

3. Öğrencinin değerini pekiştirmesi için ve ya bu değerinden emin olasına yardımcı olmak için; "Diğer olasıllkları da düşünün (öğrencilerin seçimlerinin zıddını veya farklı olasıllklar sunarak yardımcı olunabilir)... sizce o olasıllkların sonuçları neler olabilir? Şimdi ne düşünüyorsun? Senin için en değerli olanı, seni mutlu edecek olanı hangisi? Düşün. Bu düşünceni bizimle paylaşmayabilirsin çünkü sonuçlarını düşündün, durumun farkındasın, bu senin hayatın ve senin seçimin artık nasıl davranacağına karar verirsin. Elbette ki istersen bu düşünceni bizimle paylaşmakta da serbestsin. 